К. Б. Малышев https://orcid.org/0000-0003-2985-3341
О. А. Малышева https://orcid.org/0000-0002-0160-0759

Профессиональные типы и ценностные ориентации личности

Для цитирования: Малышев К. Б., Малышева О. А. Профессиональные типы и ценностные ориентации личности // Ярославский педагогический вестник. 2020. № 5 (116). С. 129-139.

DOI 10.20323/1813-145X-2020-5-116-129-139

В работе применяется базисный метод к исследованию типологии ценностей личности. Базис - это полное, упорядоченное, измеримое множество элементов. В нашем случае элементами являются типы личности. Полноту определяет факторное дихотомическое типологическое множество. Упорядоченность обеспечивается единой дихотомической многомерной базисной словесной структурой множества типов (единый дихотомический словесный многомерно-типологический базис или «словесный базис»). Измеримость типов связана с единой дихотомической числовой многомерной базисной оценочной симметрической шкалой или с «числовым базисом». Полнота связана с традиционным дихотомическим факторным анализом типологической информации (напоминает факторную стратегию Кеттелла в его типологии качеств личности). Упорядоченность задает дихотомическую базисную многомерность в словесной типологической информации. Измеримость дает возможность создания базисных многомерных методик на основе дихотомической симметрической числовой шкальной оценки типов.

Многомерный измерительный типологический базис личности - это объединение нескольких одномерных измерительных типологических базисов с единой личностной дихотомией «социальное-индивидуальное». При типологизации информации о ценностях личности можно выделить три уровня системности. Первый уровень системности соответствует традиционному хаотическо-эклектическому дихотомическому факторному отражению информации о ценностях личности. Второй уровень системности соответствует функциональной структурной связности при словесной дихотомической многомерной базисной регуляции типов ценностей личности. Третий уровень системности соответствует проектно-мерной дихотомической многомерной базисной реализации оценочно-числовой измеримости типов ценностей личности. Данная стратегия исследования связана со всеми тремя уровнями системности, лежит в основе нашей дихотомической факторной многомерной базисной измерительной типологической концепции, определяет стратегию и этапы данного исследования. В данной статье проверяется на «базисность» типология ценностей личности. Для этого на основе принципа семантической близости устанавливается взаимно-однозначное соответствие («типологический изоморфизм») типологии ценностей личности и профессиональных типов личности по Д. Голланду. В статье используется метод «базисного наложения» этих двух типологий, что обеспечивает их смысловую общность и порождает такое психологическое понятие, как «профессиональные ценности».

Ключевые слова: факторная дихотомическая типологизация, системность, многомерность, базисность, измеримость, профессиональные типы, ценностные ориентации, ценности, направленность, профиль, семантическая близость.

\title{
LABOUR PSYCHOLOGY, ENGENEERING PSYCHOLOGY, ERGONOMICS
}

\section{K. B. Malyshev, O. A. Malysheva}

\section{Professional types and value orientations of the individual}

The basic method is applied to the study of the typology of personal values. A basis is a complete, ordered, measurable set of elements. In our case, the elements are personality types. Completeness is determined by a factorial dichotomous typological set. Orderliness is determined by a single dichotomous multi-dimensional basic word structure

(C) Малышев К. Б., Малышева О. А., 2020 
of a set of types (a single dichotomous multi-dimensional-typological basis or «word basis»). The measurability of types is associated with a single dichotomous numerical multidimensional basic evaluation symmetric scale or with a «numerical basis». Completeness is related to the traditional dichotomous factor analysis of typological information (it resembles the factor strategy of Kettell in his typology of personality qualities). Orderliness sets a dichotomous basic multidimensionality in verbal typological information. Measurability makes it possible to create basic multidimensional methods based on a dichotomous symmetric numerical scale estimation of types.

Multidimensional measuring typological basis of personality is a combination of several one-dimensional measuring typological bases with a single personal dichotomy «social-individual». In typology of information about the values of the personality is possible to allocate three levels of consistency. The first level of consistency corresponds to the traditional chaotic-eclectic dichotomous factor representation of information about personal values. The second level of consistency corresponds to functional structural coherence in the verbal dichotomous multidimensional basic regulation of the types of values of the individual. The third level of consistency corresponds to the project-dimensional dichotomous multidimensional basic implementation of the estimated-numerical measurement of the types of values of the individual. This research strategy is related to all three levels of systemicity, it is the basis of our dichotomous factor multidimensional base measurement typological concept, and it defines the strategy and stages of this research. In this article, the typology of personal values is checked for «basicity». For this purpose, based on the principle of semantic proximity, one-to-one correspondence («typological isomorphism») is established between the typology of personal values and professional personality types according to D. Holland. The article uses the method of «basic superimposition» of these two typologies, which provides a semantic community of these two typologies and generates such a psychological concept as «professional values».

Keywords: factorial dichotomous typology, system, multi-dimensionality, basicity, measurability, professional types, value orientations, values, orientation, profile, semantic proximity.

Актуальность исследования. Профессиональные затруднения практического психолога связаны с выбором конкретных методик, применяемых в работе. Ему необходимо иметь определенный набор психодиагностических средств, которые он мог бы эффективно использовать в своей практической деятельности. В теоретических исследованиях, направленных на создание диагностических методик, важно учитывать механизм типологизации психологических характеристик личности. Большой проблемой для практических психологов является разработка собственных методик, необходимых для частных и особенных случаев изучения личности. Для этого требуются технологии создания психолого-педагогического диагностического инструментария, который позволил бы расширить и показать целостную картину личности.

Изучением личностных характеристик и последующей их типологизацией занимались как отечественные, так и зарубежные исследователи (Б. Г. Ананьев, А. Г. Асмолов, Л. И. Анцыферова, Г. Айзенк, Р. Брэмсон, Э. Берн, Е. А. Климов, Н. В. Кузьмина, Р. Кеттелл, К. Леонгард, А. Харрисон, Э. Г. Эйдемиллер, В.В.Юстицкис, К. Г. Юнг и др.). Многие отечественные, а также заимствованные из зарубежного опыта диагностические методики применяются без предварительного теоретического анализа полноты и упорядоченности психологических характеристик, входящих в типологическую структуру исследуемого понятия. Одна из причин этого - несовер- шенство самих психологических типологий, их рассогласованность с конкретными методиками.

С одной стороны, существуют типологии без соответствующего диагностического обеспечения. С другой - есть методики, для которых не предлагается предварительной теоретической модели типологизации. Во всех этих типологиях и методиках измерений отсутствует предварительный теоретический анализ полноты и упорядоченности информации о характеристиках личности. Потребности практической психологии определяют социальный заказ на разработку технологии типологизации психологических характеристик личности. На основании теоретического анализа проблемы исследования и ее актуальности было выявлено противоречие между существующими методиками получения информации о ценностях личности, дающими неполную картину в этом направлении, и необходимостью разработки технологии для создания методики измерения ценностей, обеспечивающих представление о полной и упорядоченной типологической модели ценностей личности. Стремление найти пути разрешения указанного противоречия определило проблему нашего исследования.

Объект исследования - информация о типологических психологических характеристиках личности. Предмет исследования - многомерный типологический подход как механизм конструирования методики, обеспечивающей получение полной, упорядоченной и измеримой информации о ценностных характеристиках личности. Цель ис- 
следования - создание новой методики для получения и измерения информации о ценностях личности на основе применения многомерного системно-базисного типологического подхода. $\Gamma u$ потеза исследования состоит в том, что определение и измерение ценностей личности связано с многомерным измерительным типологическим базисом ее профессиональной направленности.

Исходя из поставленной цели и сформулированной гипотезы были поставлены следующие задачи:

- выявить теоретические основания получения информации о типологических базисных характеристиках личности;

- определить теоретические основания разработки многомерного типологического системно-базисного подхода к получению информации о ценностных характеристиках личности;

- создать алгоритм построения системнобазисного многомерного типологического конструкта для получения соответствующей многомерной базисной методики измерения типологических характеристик ценностей личности.

Новизна исследования заключается в расширении представления о системно-базисной методологии описания, измерения понятий в психологии и соответствующего конструирования диагностических средств, что очень важно в работе практического психолога, в раскрытии сущности понятия «многомерный базисный типологический подход», который будет способствовать развитию творческого мышления теоретического психолога, в определении теоретических оснований для разработки многомерного базисного типологического подхода к получению информации о типологических характеристиках ценностей личности, в создании алгоритма построения нового системнобазисного многомерного типологического конструкта (создания новой типологии ценностей личности) для получения соответствующей многомерной базисной методики измерения типологических характеристик ценностей личности, в разработке новой методики, позволяющей измерять многомерный базисный типологический профиль ценностей личности, в разработке новой многомерной базисной педагогической технологии для преподавания психологических дисциплин.

Теоретическая значимость исследования заключается в том, что результаты исследования расширяют научное представление о роли и значении процессов структурирования психологической информации о личности на основе примене- ния системно-базисного многомерного подхода, что в свою очередь будет способствовать развитию творческого мышления теоретического психолога. Результаты исследования позволяют осуществить единый многомерный типологический подход к решению проблем обеспечения практического психолога диагностическим инструментарием, расширяют представление о базисной многомерной технологии описания и измерения информации о ценностях личности, что, в свою очередь, поможет практическим психологам эффективно работать в диагностическом направлении.

Практическая значимость исследования состоит в том, что его результаты направлены на получение полной и качественной информации о характеристиках личности на основе применения многомерного типологического подхода. Они позволяют усовершенствовать измерение ценностей личности. Применение результатов исследования даст возможность улучшить практическое диагностическое обеспечение психолога. Информация, полученная в результате исследования, может быть использована для творческого развития практического психолога при проведении психодиагностики, организации консультирования, при проведении тренингов, деловых игр и др. Результаты исследования можно использовать для улучшения качества преподавания психологических дисциплин в учебных заведениях. Основные положения данного подхода можно, в частности, применять для расширения содержания учебного курса «Психодиагностика».

Психодиагностическая работа выполнялась на базе Вологодского госуниверситета. Было проведено диагностическое обследование студентов этого университета в количестве 209 человек.

Определим базисные понятия «ценностные ориентацчии», «направленность», «ценности». Ценностные ориентации отражают содержательную сторону направленности личности и составляет основу ее отношений к окружающему миру, к другим людям, к себе самой, основу мировоззрения и ядро мотивации жизненной активности, основу жизненной концепции и «философии жизни». Направленность личности - это регулируемая система, устойчиво характеризующая побуждения человека (что человек хочет, к чему стремится, так или иначе понимая мир, общество; чего избегает, против чего готов бороться). При этом она достаточно динамична, то есть составляющие побуждения личности не остаются постоянными, они взаимосвязаны, влияют друг на 
друга, изменяются и развиваются. Ценности выполняют реализуюшую функцию в отношении выбора жизненных приоритетов, это вещи, принципы, идеалы, нравственные нормы, это то, что люди считают важным в своей жизни, что образует цели и мотивы их деятельности, к чему они стремятся, достижение чего образует смысл их жизни. Они определяют потребности, интересы, убеждения, жизненные планы, судьбу человека, его взаимоотношения с людьми. Это наше «рабочее» определение «изенностей», которого мы придерживаемся и которое используем в данном исследовании (два других базисных понятия «иеенностные ориентации» $u$ «направленность» нами не используются). В современной психологии выделяют три основные функции психики: «отражение», «регуляция» и «реализация», которые образуют трехмерный базис с субстратом «функции психики» и с единой обобщенной дихотомией «внешнее - внутреннее» [Малышев, 2019]. Понятия-факторы («цеенностные ориентацчии», «направленность» $u$ «иеенности») образуют также трехмерный базис с субстратом «ценностная позиция личности» и с единой обобщенной дихотомией «внешнее - внутреннее», что устанавливается при их взаимно-однозначном соответствии на основе принципа семантической близости с тремя вышеуказанными основными «функциями психики» («функционально-факторный изоморфизм») [Малышев, 2019]. В данном случае эти понятия разведены и образуют линейно независимую систему факторов и тем самым - «трехмерный факторный базис» с единой обобщенной дихотомией «внешнее - внутреннее».

В мировой психологии существует огромное количество работ, где изучаются ценностные ориентации, направленность, ценности и их иерархия. В этих работах отражается хаотическоэклектическое описание этих трех понятийфакторов, определяющее первый уровень системности, и делаются попытки установления связи между этими понятиями. Нормативноценностный подход изучения менталитета общества идет от Э. Дюркгейма, Т. Парсонса, М. Вебера, А. Маршалла, В. Парето. Много лет этой проблематикой занимались американские ученые, такие как У. Томас, Ф. Знанецкий, Дж. Мид. В большинстве современных исследований ценности рассматриваются под социальнопсихологическим углом зрения, предстают как социальное явление (А. И. Донцов, Д. А. Леонтьев), как продукт жизнедеятельности общества и социальных групп.
С содержательной стороны изенности указывают, какие идеи, принципы, цели поведения являются важными. Одну из первых типологизаций ценностей предложил Г. Олпорт. Он выделил шесть типов иееностей: теоретические, которые придают наибольшую важность и значение рациональному мышлению и поиску истины; экономические ценности, утверждающие приоритет практической пользы и выгоды; эстетические ценности, выше всего ставящие красоту, гармонию и искусство; социальныле ценности, придающие наибольшее значение человеческим взаимоотношениям - любви, дружбе, преданности и т. д.; политические ценности, отдающие исключительное предпочтение обретению власти и влияния; религиозные ценности, которые первостепенную важность придают следованию определенной системе представлений (вере). Данную типологию можно поставить во взаимно-однозначное соответствие типологии профессиональной направленности личности, по Д. Голланду, используя принцип семантической близости и метод «наложения» базисов: экономические ценности (конвенциальный тип) - эстетические ценности (артистический тип); сочииальные ценности (социальный тип) - религиозные ценности (реалистический тип); политические ценности (предприимчивый тип) - теоретические ценности (интеллектуальный тип) с единой дихотомией «социальное индивидуальное».

Методика Д. Голланда (см. Табл. 1) и определение профессиональных типов личности приводится в Таблице 2. М. Рокич разделяет ценности на две большие группы: терминальные (ценности-цели) и инструментальные (ценностисредства) [Малышев, 2019].

К первой группе относятся цуенности, которые выступают базовыми. В соответствии с ними индивид строит свою жизнь, готов их отстаивать и укреплять. Эта группа включает такие ценности, как человеческое достоинство, любовь, дружба, экономическое процветание, безопасность, равенство возможностей и т. Д. Их можно рассматривать как общечеловеческие, универсальные нравственные стандарты, которые, по-видимому, одинаково важны в любой стране и культуре. Ко второй группе относятся цุенности, имеющие более конкретный поведенческий смысл. Они могут быть обозначены прилагательными, в которых отражены виды поведения, одобряемые или отвергаемые индивидом. Эти ценности могут быть выражены такими прилагательными, как тактичный, преданный, компетентный, патриотичный, 
вежливый и т. д. Так, согласно исследованиям М. Рокича, иенность есть устойчивое убеждение, это определенный способ поведения или существования, который может быть индивидуально или социально предпочтительным.

\section{Методика Д. Голланда на определение профнаправленности личности}

Ниже попарно приведены различные профессии. По каждой паре профессий предпочтение отмечается $(+)$ в листе ответов.

\begin{tabular}{|c|c|c|c|c|c|}
\hline $\begin{array}{l}1 \\
\text { a) инженер-техник } \\
\text { б) инженер- } \\
\text { контролер } \\
\end{array}$ & $\begin{array}{l}2 \\
\text { a) вязальщик } \\
\text { б) санитарный врач }\end{array}$ & $\begin{array}{l}3 \\
\text { a) повар } \\
\text { б) наборщик }\end{array}$ & $\begin{array}{l}4 \\
\text { a) фотограф } \\
\text { б) заведующий } \\
\text { магазином } \\
\end{array}$ & $\begin{array}{l}5 \\
\text { a) чертежник } \\
\text { б) дизайнер }\end{array}$ & $\begin{array}{l}6 \\
\text { a) философ } \\
\text { б) психиатр }\end{array}$ \\
\hline $\begin{array}{l}7 \\
\text { a) ученый- химик } \\
\text { б) бухгалтер }\end{array}$ & $\begin{array}{l}8 \\
\text { a) редактор научно- } \\
\text { го журнала } \\
\text { б)адвокат }\end{array}$ & $\begin{array}{l}9 \\
\text { a) лингвист } \\
\text { б) переводчик ху- } \\
\text { дожественной ли- } \\
\text { тературы } \\
\end{array}$ & $\begin{array}{l}10 \\
\text { a) педиатр } \\
\text { б)статистик }\end{array}$ & $\begin{array}{l}11 \\
\text { a) организатор вос- } \\
\text { питательной работы } \\
\text { б) предприниматель }\end{array}$ & $\begin{array}{l}12 \\
\text { a) спортивный врач } \\
\text { б) фельетонист }\end{array}$ \\
\hline $\begin{array}{l}13 \\
\text { a) нотариус } \\
\text { б) снабженец }\end{array}$ & $\begin{array}{l}14 \\
\text { a) перфоратор } \\
\text { б) карикатурист }\end{array}$ & $\begin{array}{l}15 \\
\text { a) политический } \\
\text { деятель } \\
\text { б) писатель }\end{array}$ & $\begin{array}{l}16 \\
\text { a) садовник } \\
\text { б) метеоролог }\end{array}$ & $\begin{array}{l}17 \\
\text { а) водитель трол- } \\
\text { лейбуса } \\
\text { б) медсестра }\end{array}$ & $\begin{array}{l}18 \\
\text { a) инженер- } \\
\text { электрик } \\
\text { б) секретарь- } \\
\text { машинистка } \\
\end{array}$ \\
\hline $\begin{array}{l}19 \\
\text { a) маляр } \\
\text { б) художник по ме- } \\
\text { таллу } \\
\end{array}$ & $\begin{array}{l}20 \\
\text { a) биолог } \\
\text { б) главный врач }\end{array}$ & $\begin{array}{l}21 \\
\text { a) телеоператор } \\
\text { б)режиссер }\end{array}$ & $\begin{array}{l}22 \\
\text { a) гидролог } \\
\text { б) ревизор }\end{array}$ & $\begin{array}{l}23 \\
\text { a) зоолог } \\
\text { б) зоотехник }\end{array}$ & $\begin{array}{l}24 \\
\text { а) математик } \\
\text { б) архитектор }\end{array}$ \\
\hline $\begin{array}{l}25 \\
\text { a) социальный ра- } \\
\text { ботник } \\
\text { б) счетовод } \\
\end{array}$ & $\begin{array}{l}26 \\
\text { a) учитель } \\
\text { б)директор фирмы }\end{array}$ & $\begin{array}{l}27 \\
\text { a) воспитатель } \\
\text { б) художник по } \\
\text { керамике } \\
\end{array}$ & $\begin{array}{l}28 \\
\text { а) экономист } \\
\text { б) заведующий от- } \\
\text { делом } \\
\end{array}$ & $\begin{array}{l}29 \\
\text { a) корректор } \\
\text { б) критик }\end{array}$ & $\begin{array}{l}30 \\
\text { a) завхоз } \\
\text { б) директор }\end{array}$ \\
\hline $\begin{array}{l}1 \\
\text { a) радиоинженер } \\
\text { б) специалист по } \\
\text { ядерной физике } \\
\end{array}$ & $\begin{array}{l}32 \\
\text { a) наладчик } \\
\text { б) механик }\end{array}$ & $\begin{array}{l}33 \\
\text { a) агроном } \\
\text { б) управляющий } \\
\text { отелем } \\
\end{array}$ & $\begin{array}{l}34 \\
\text { a) закройщик- } \\
\text { модельер } \\
\text { б) декоратор } \\
\end{array}$ & $\begin{array}{l}5 \\
\text { a) археолог } \\
\text { б) эксперт }\end{array}$ & $\begin{array}{l}36 \\
\text { a) работник музея } \\
\text { б) консультант }\end{array}$ \\
\hline $\begin{array}{l}37 \\
\text { a) ученый } \\
\text { б) актер }\end{array}$ & $\begin{array}{l}38 \\
\text { a) логопед } \\
\text { б) стенографист }\end{array}$ & $\begin{array}{l}39 \\
\text { a) врач } \\
\text { б)дипломат }\end{array}$ & $\begin{array}{l}40 \\
\text { a) главный бухгал- } \\
\text { тер } \\
\text { б)директор } \\
\end{array}$ & $\begin{array}{l}11 \\
\text { a) поэт } \\
\text { б)психолог }\end{array}$ & $\begin{array}{l}42 \\
\text { a) архивариус } \\
\text { б) скульптор }\end{array}$ \\
\hline
\end{tabular}

Ключ кметодике

\begin{tabular}{|l|l|}
\hline Социальный & $26,66,10 \mathrm{a}, 11 \mathrm{a}, 12 \mathrm{a}, 176,206,25 \mathrm{a}, 26 \mathrm{a}, 27 \mathrm{a}, 366,38 \mathrm{a}, 39 \mathrm{a}, 416$ \\
\hline Артистический & $56,96,126,146,156,196,216,246,276,296,306,346,41 \mathrm{a}, 426$ \\
\hline Предприимчивый & $46,86,116,136,15 \mathrm{a}, 236,266,286,30 \mathrm{a}, 336,356,376,396,406$ \\
\hline Интеллектуальный & $16,6 \mathrm{a}, 7 \mathrm{a}, 8 \mathrm{a}, 9 \mathrm{a}, 166,20 \mathrm{a}, 22 \mathrm{a}, 23 \mathrm{a}, 24 \mathrm{a}, 316,35 \mathrm{a}, 36 \mathrm{a}, 37 \mathrm{a}$ \\
\hline Конвенциальный & $36,76,106,13 \mathrm{a}, 14 \mathrm{a}, 186,226,256,28 \mathrm{a}, 29 \mathrm{a}, 326,386,40 \mathrm{a}, 42 \mathrm{a}$ \\
\hline Реалистический & $1 \mathrm{a}, 2 \mathrm{a}, 3 \mathrm{a}, 4 \mathrm{a}, 5 \mathrm{a}, 16 \mathrm{a}, 17 \mathrm{a}, 18 \mathrm{a}, 19 \mathrm{a}, 21 \mathrm{a}, 31 \mathrm{a}, 32 \mathrm{a}, 33 \mathrm{a}, 34 \mathrm{a}$ \\
\hline
\end{tabular}

Система ценностей есть устойчивая совокупность убеждений. Выделяя три типа убеждений (экзистенциальные, оценочные и прогностические), М. Рокич относит ценности к последнему, третьему, типу, позволяющему ориентироваться в желательности-нежелательности способа поведения (операциональные, инструментальные ценности) и существования (смысловые, терминальные ценности).

При анализе типологии цзенностей можно использовать многомерный системно-базисный подход (многомерный измерительный типологический базис - это полное, упорядоченное и измерительное множество типов). На основе принципа семантической близости, сопоставляя две типологии, одна из которых взята за эталонный базис, устанавливаем их взаимно-однозначное соответствие [Ганзен, 1984; Малышев, 2019]. Дадим характеристику типологии личности по Д. Голланду, взятую за эталонный семантический типологический базис [Малышев, 2019], и сравним ее с множеством типов ценностей (см. Табл. 2). В типологии личности по Д. Голланду обнаруживается единая обобщенная дихотомия «внешнее - внутреннее», которая понимается нами, в частности, как «социальное - индивидуальное». Практика показывает, что определенный тип профессиональной направленности личности будет ярко 
проявляться в определенном наборе ценностей личности [Малышев, 2019]. В результате указанного соответствия получаем трехмерную базисную типологию ценностей личности: «нормативные - эстетические», «духовные - материальные», «организаторские - исследовательские» с единой дихотомией «социальное - индивидуальное».

Эта типология соответствует трехмерной базисной типологии профессиональной направленности личности по Д. Голланду: «конвенциальный - артистический», «социальный - реалистический», «предприимчивый - интеллектуальный».
«Наложение» двух трехмерных типологических базисов личности (профессиональной направленности и ценностей) на основе использования принципа семантической близости имеет большую смысловую общность и порождает новое субстратное понятие «профессиональные ценности». Можно построить 64 гексаграммы профиля ценностей личности, где наличие или отсутствие определенной ценности будет обозначаться, соответственно, сплошной или разорванной черточкой (см. рис. 1).

Таблица 2

Сравнительный анализ типологии профессиональной направленности и типов цеенностей личности

\begin{tabular}{|c|c|c|}
\hline $\begin{array}{l}\text { Личностный трехмерный профессио- } \\
\text { нальный типологический базис } \\
\text { (по Д. Голланду) }\end{array}$ & Типы ценностей личности & $\begin{array}{l}\text { Утверждения для теста «Типы иен- } \\
\text { ностей личности» }\end{array}$ \\
\hline $\begin{array}{l}\text { Предприимчивый тип стремится к руко- } \\
\text { водству другими людьми, социален, лю- } \\
\text { бит организационную работу, активен, в } \\
\text { поведении опирается часто на эмоции, } \\
\text { своей волей может подавлять волю дру- } \\
\text { гих людей, для него важны статус и } \\
\text { власть. Бессистемен в мышлении, отбира- } \\
\text { ет лучшее из разных систем мысли, обла- } \\
\text { дает эклектическим умом, порой ему не } \\
\text { хватает вкуса и чувства меры. «Смешива- } \\
\text { ет несоединимое». Использует все для } \\
\text { получения результата и стремится любой } \\
\text { ценой получить прибыль. Адаптатор, } \\
\text { экспериментатор, инноватор. Использует } \\
\text { практику и теорию для достижения цели. } \\
\text { При воздействии на людей может умело } \\
\text { использовать тактику и стратегию пове- } \\
\text { дения. Не теряется в сложных жизненных } \\
\text { ситуациях }\end{array}$ & $\begin{array}{l}\text { Организаторские ценности. Вклю- } \\
\text { чают желание человека заниматься } \\
\text { организаторской деятельностью, реа- } \\
\text { лизуя себя в качестве руководителя, } \\
\text { при этом проявляя экспрессивность, } \\
\text { предприимчивость, властность, а по- } \\
\text { рой даже и агрессивность. Человек } \\
\text { любит доминировать, и для него важно } \\
\text { общественное признание людей (до- } \\
\text { минирующее эгосостояние - это } \\
\text { «Взрослый организующий») }\end{array}$ & $\begin{array}{l}\text { 1. Мне нравится заниматься органи- } \\
\text { зацией и руководить другими людь- } \\
\text { ми. } \\
\text { 2. В поведении я проявляю предпри- } \\
\text { имчивость, экспрессивность, власт- } \\
\text { ность, эмоциональность, а порой и } \\
\text { агрессивность. } \\
\text { 3. Я чаще доминирую в отношениях, } \\
\text { стремясь к общественному призна- } \\
\text { нию }\end{array}$ \\
\hline $\begin{array}{l}\text { Интеллектуальный тип в поведении про- } \\
\text { являет свою индивидуальность, аналити- } \\
\text { ческий склад ума, рациональность, креа- } \\
\text { тивность, стремится к интеллектуальному } \\
\text { труду, к исследованиям. Предпочитает } \\
\text { дедуктивный способ в мышлении. Отбира- } \\
\text { ет «самый эффективный способ» в дея- } \\
\text { тельности, стремится к формально- } \\
\text { логическим рассуждениям. Опирается на } \\
\text { формулы и модели в деятельности и стре- } \\
\text { мится к «научным решениям», к правилам, } \\
\text { предписаниям и нормативности. Склонен к } \\
\text { теории и методу, а не к практическим дан- } \\
\text { ным. Любит плановую работу, речевую } \\
\text { детализацию, результативен, стабилен в } \\
\text { структурированной деятельности }\end{array}$ & $\begin{array}{l}\text { Исследовательские ценности- это } \\
\text { стремление к абстрактным размышле- } \\
\text { ниям, решение интеллектуальных за- } \\
\text { дач. Это любознательность, стремле- } \\
\text { ние учиться, познавать, исследовать, } \\
\text { узнавать что-то новое, умение прово- } \\
\text { дить эксперименты, заниматься раз- } \\
\text { ными расследованиями, диагностикой, } \\
\text { желание быть юристом-следователем, } \\
\text { «следопытом» (доминирующее эгосо- } \\
\text { стояние - «Взрослый познающий») }\end{array}$ & $\begin{array}{l}\text { 4. Люблю решать задачи, требующие } \\
\text { абстрактного мышления. } \\
\text { 5. Я человек любопытный, и мне } \\
\text { всегда нравится чему-либо учиться. } \\
\text { 6. Меня привлекает работа исследо- } \\
\text { вателя }\end{array}$ \\
\hline $\begin{array}{l}\text { Социальный тип коммуникабелен, про- } \\
\text { являет социальную направленность в } \\
\text { поведении, коллегиален в принятии ре- } \\
\text { шений, любит советоваться с другими } \\
\text { людьми, дружелюбен. Находит сходство } \\
\text { во внешне, казалось бы, несовместимых } \\
\text { вещах. Учитывает разные мнения, взгля- } \\
\text { ды, стремится к нормативности, к идеаль- } \\
\text { ным решениям, к человеческим ценно- } \\
\text { стям, к синтезу, может через конфликт }\end{array}$ & $\begin{array}{l}\text { Духовные ценности - это чуткость, } \\
\text { справедливость, самосовершенст- } \\
\text { вование, красота, семья, любовь, ми- } \\
\text { лосердие, честность, воспитанность, } \\
\text { активно-деятельная жизнь, жизненная } \\
\text { мудрость, знания, книги, дружба, сме- } \\
\text { лость, труд, ответственность, творче- } \\
\text { ство, свобода, забота, опека, воспита- } \\
\text { ние людей, помощь людям, советы при } \\
\text { необходимости, эмпатия, сопережива- }\end{array}$ & $\begin{array}{l}\text { 7. К людям проявляю чуткость, чест- } \\
\text { ность, справедливость, любовь, ми- } \\
\text { лосердие. Мне нравится воспиты- } \\
\text { вать, заботиться, опекать других } \\
\text { людей. } \\
\text { 8. По отношению к людям я прояв- } \\
\text { ляю дружелюбие, смелость, ответ- } \\
\text { ственность, люблю давать советы, } \\
\text { помогать, проявляю творчество. } \\
\text { 9. Эмпатия, сопереживание и сочув- }\end{array}$ \\
\hline
\end{tabular}


Ярославский педагогический вестник - 2020 - № 5 (116)

\begin{tabular}{|c|c|c|}
\hline $\begin{array}{l}\text { Личностный трехмерный профессио- } \\
\text { нальный типологический базис } \\
\text { (по Д. Голланду) } \\
\end{array}$ & Типы ценностей личности & $\begin{array}{l}\text { Утверждения для теста «Типы иеен- } \\
\text { ностей личности» }\end{array}$ \\
\hline $\begin{array}{l}\text { решать определенные задачи. Любит ди- } \\
\text { намику изменений, сензитивен. Предста- } \\
\text { вители этого типа зависимы, зачастую } \\
\text { проявляют пассивность в деятельности, } \\
\text { привлекают на помощь других людей. } \\
\text { Большое желание быть любимыми, } \\
\text { меньше - любить других, развито целепо- } \\
\text { лагание, в неструктурированных ситуаци- } \\
\text { ях проявляют хорошую ориентацию }\end{array}$ & $\begin{array}{l}\text { ние и сочувствие (доминирующее эго- } \\
\text { состояние - «Родитель воспитываю- } \\
\text { щий») }\end{array}$ & $\begin{array}{l}\text { ствие - главные черты моего харак- } \\
\text { тера }\end{array}$ \\
\hline $\begin{array}{l}\text { Pеалистический тип любит конкретно- } \\
\text { предметный труд, индивидуален, разби- } \\
\text { рается в математике. Точность, контроль, } \\
\text { нормативность поведения. Недружелю- } \\
\text { бен, индуктивен, эмпирик, опирается на } \\
\text { факты и мнения экспертов. Хорошо ре-- } \\
\text { шает реальные, конкретные задачи, может } \\
\text { по ходу дела корректировать свою и чу- } \\
\text { жую деятельность. Для него важны фак- } \\
\text { ты, результат, а не теория. Учитывает } \\
\text { ресурсы, прагматичен, экономит средства, } \\
\text { склонен к приобретению вещей, к боль- } \\
\text { шой зарплате, к обогащению, может иг- } \\
\text { норировать и избегать «просителей». Ре- } \\
\text { зультативный, импульсивный, целена- } \\
\text { правленный, энергичный, мотивирующий } \\
\text { себя и людей на практическую деятель- } \\
\text { ность }\end{array}$ & $\begin{array}{l}\text { Материальные ценности - это еда, } \\
\text { «вещизм», стремление заработать } \\
\text { деньги, приобрести автомобиль, гараж, } \\
\text { драгоценности, дом, квартиру, косме- } \\
\text { тику, музыкальные инструменты, } \\
\text { одежду, компьютер, магнитофон, те- } \\
\text { лефон, спортивные принадлежности, } \\
\text { мебель. Это прагматизм, предметный } \\
\text { труд, изготовление чего-то руками, } \\
\text { манипуляция с вещами, работа на } \\
\text { компьютере (доминирующее эгососто- } \\
\text { яние - «Родитель контролирующий») }\end{array}$ & $\begin{array}{l}\text { 10. Мне нравится заниматься кон- } \\
\text { кретно-предметным трудом и изго- } \\
\text { тавливать что-то руками дома в га- } \\
\text { раже, на даче, ездить на автомобиле, } \\
\text { благоустраивать квартиру и дом. } \\
\text { 11. Я стремлюсь к практической дея- } \\
\text { тельности, к манипуляции с вещами, } \\
\text { люблю переставлять мебель. } \\
\text { 12. Я стремлюсь к приобретению } \\
\text { вещей, мебели, одежды, к получению } \\
\text { больших зарплат }\end{array}$ \\
\hline $\begin{array}{l}\text { Артистический тип независим в поведе- } \\
\text { нии, индивидуален, креативен, импульси- } \\
\text { вен, энергичен, динамичен, проявляет } \\
\text { доминирующую позицию в общении. Хо- } \\
\text { роший импровизатор, эстетичен в дея- } \\
\text { тельности, находит общее в различных } \\
\text { вещах и явлениях. Любит динамику из- } \\
\text { менений в окружающей среде. Спокойно } \\
\text { относится к недоказательной аргумента- } \\
\text { ции, опирается на основополагающие } \\
\text { принципы, к людям неравнодушен, в дея- } \\
\text { тельности опирается на теорию, отвергает } \\
\text { соглашательство в политике, а также не- } \\
\text { обоснованные решения, уверенно ведет } \\
\text { себя в спорной ситуации, может иниции- } \\
\text { ровать творчество в группе }\end{array}$ & $\begin{array}{l}\text { Эстетические ценности - это } \\
\text { стремление к музыке, поэзии, к созда- } \\
\text { нию хорошего эмоционального } \\
\text { настроения у людей, богатая фантазия } \\
\text { и воображение. Человек обладает } \\
\text { утонченным эстетическим восприяти- } \\
\text { ем мира и может оценить художе- } \\
\text { ственное искусство. Ему нравится } \\
\text { творчество писателей, и он любит чи- } \\
\text { тать художественные произведения } \\
\text { (доминирующее эгосостояние - «Дитя } \\
\text { свободное») }\end{array}$ & $\begin{array}{l}\text { 13. Я стремлюсь к музыке, поэзии, и } \\
\text { это создает у меня хорошее эмоцио- } \\
\text { нальное настроение. } \\
\text { 14. У меня богатая фантазия, вооб- } \\
\text { ражение и утонченное эстетическое } \\
\text { восприятие окружающего мира. } \\
\text { 15. Могу оценить художественное } \\
\text { искусство, мне нравится творчество } \\
\text { писателей, читаю художественную } \\
\text { литературу }\end{array}$ \\
\hline $\begin{array}{l}\text { Конвенциальный тип предпочитает четко } \\
\text { структурированную деятельность, социа- } \\
\text { лен, в поведении стремится к подчинению, } \\
\text { признает социальные нормы в поведении } \\
\text { и в работе, любимые занятия - канцеля- } \\
\text { рия, делопроизводство, имеет математи- } \\
\text { ческие способности. Любит технологиче- } \\
\text { скую, структурированную, деятельность. } \\
\text { Больше методолог, а не теоретик. В рабо- } \\
\text { те использует апробированные методики, } \\
\text { строго соблюдает последовательность } \\
\text { выполнения этапов в деятельности. Тех- } \\
\text { нолог от природы, любит контролировать } \\
\text { свою и чужую работу, нормативен. Дис- } \\
\text { циплинирован, упорядочен, системен в } \\
\text { работе }\end{array}$ & $\begin{array}{l}\text { Нормативные ценности - это } \\
\text { стремление к дисциплине и соблюде- } \\
\text { нию социальных правил и норм в об- } \\
\text { ществе. Человек любит порядок, си- } \\
\text { стемность, технологичность, програм- } \\
\text { мирование, умеет приспособиться и } \\
\text { выполняет требования социального } \\
\text { окружения, стремится к нормативному } \\
\text { поведению, проявляет сдержанность и } \\
\text { спокойствие в ситуациях спора и кон- } \\
\text { фликта (доминирующее эго - } \\
\text { состояние - «Дитя адаптивное») }\end{array}$ & $\begin{array}{l}\text { 16. В своем поведении соблюдаю } \\
\text { правила, дисциплину, нормы и тре- } \\
\text { бования общества. } \\
\text { 17. Могу адаптироваться, изменить } \\
\text { свое поведение под влиянием социу- } \\
\text { ма. } \\
\text { 18. Я люблю порядок системность, } \\
\text { технологичность и программирова- } \\
\text { ние в работе. Мне нравится рассуж- } \\
\text { дать, а в споре я проявляю сдержан- } \\
\text { ность и спокойствие }\end{array}$ \\
\hline
\end{tabular}




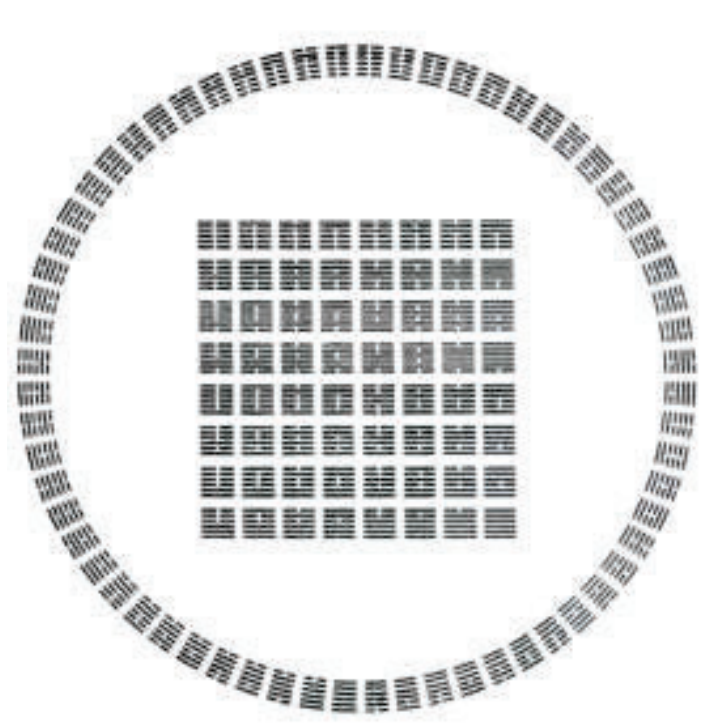

Рис. 1. Профили цеенностей личности, состоящие из 64 гексаграмм

Предлагается авторская методика измерения профиля ценностей личности в виде теста, состоящего из 18 вопросов (см. Табл. 2). В таблице содержится ключ: организаторские иенности $(1,2$, 3), исследовательские иенности $(4,5,6)$, духовные иенности $(7,8,9)$, материальные иенности $(10$, $11,12)$, эстетические иенности $(13,14,15)$, нормативные иенности $(16,17,18)$.

Оценка каждого суждения проводится с использованием симметрической пятибалльной шкалы от -2 до +2: -2 (не согласен), -1 (скорее не согласен, чем согласен), 0 (неопределенный случай $),+1$ (скорее согласен, чем не согласен), +2 (согласен), которые соответствуют положительным оценкам: 1, 2, 3, 4, 5.

Мы получаем уровни выраженности типов «ценностей личности»: (3-5) - низкий уровень, (6-9) - средний уровень, (10-15) - высокий уровень.

Перепроверим на «базисность», то есть на «полноту» и «упорядоченность», авторский набор типов ценностей личности и рассмотрим реализацию многомерного типологического подхода при построении базисной типологии ценностей личности.

Для выявления полноты данной типологии был выбран эталонный семантический типологический базис- типология профессиональной направленности личности по Д. Голланду, которая включает шесть типов: конвенциальный, артистический, социальный, реалистический, предприимчивый, интеллектуальный [Малышев, 2019].
Практика показывает, что определенный тип ценностей личности будет ярко проявляться в доминирующем типе профессиональной направленности личности. Характеризуя типологию профессиональной направленности личности по Д. Голланду, следует отметить, что она является полной, упорядоченной и измеримой системой типов. «Полнота» определяется тем, что вышеуказанными шестью типами профессиональной направленности личности исчерпываются все возможные варианты профессий, которые встречаются в профессиональной сфере. «Упорядоченность» профессиональных типов личности проявляется в том, что в этом наборе существуют три пары противоположных «полюсов-типов», которые имеют единый полярный дихотомический признак «социальное - индивидуальное»: «конвенциальный - артистический», «социальный реалистический», «предприимчивый - интеллектуальный».

В результате применения принципа семантической близости удается сопоставить множество характеристик одного понятия (типы ценностей личности) с характеристиками другого эталонного базисного множества (типы профессиональной направленности личности). Это дает возможность получить типологический базисный конструкт ценностей личности (см. Табл. 2) [Малышев, 2019].

На основе полученного результата была предложена авторская методика определения профиля ценностей личности (см. диагностические суждения для опросника «Типы ценностей личности» в таблице, которая является одновременно и ключом к методике). Валидизация новой методики на измерение ценностей личности проводилась в направлении конструктивной валидности [Малышев, 2019]. Этот тип валидности отражает степень репрезентации исследуемого психологического конструкта в результатах теста. В качестве психологического конструкта выступают типы ценностей личности [Кулагин, 1984].

Результаты тестирования студентов Вологодского государственного университета, полученные с помощью новой методики определения ценностей личности, коррелируют с диагностическими результатами по методике на определение профессиональной направленности личности следующим образом [Малышев, 2019]:

- «Духовные ценности» - «Социальный тип».

- «Эстетические ценности»- «Артистический тип». 
- «Организаторские ценности»- «Предприимчивый тип».

- «Исследовательские ценности»- «Интеллектуальный тип».

- «Нормативные ценности» - «Конвенциальный тип».

- «Материальные ценности» - «Реалистический тип».

Было проведено диагностическое обследование студентов Вологодского государственного университета (209 человек). Диапазон коэффици- ентов корреляции от 0,49 до 0,65 между типами теста на определение ценностей личности и аналогичным по типологическому конструкту тестом, измеряющим типы профессиональной направленности личности и являющимся валидным, подтверждает то, что разработанный новый тест «измеряет» те же характеристики личности, что и трехмерный базисный тест-эталон на определение профессиональной направленности личности (см. Табл. 3).

Таблица 3

Корреляцуии между типами цุенностей и профессиональными типами личности

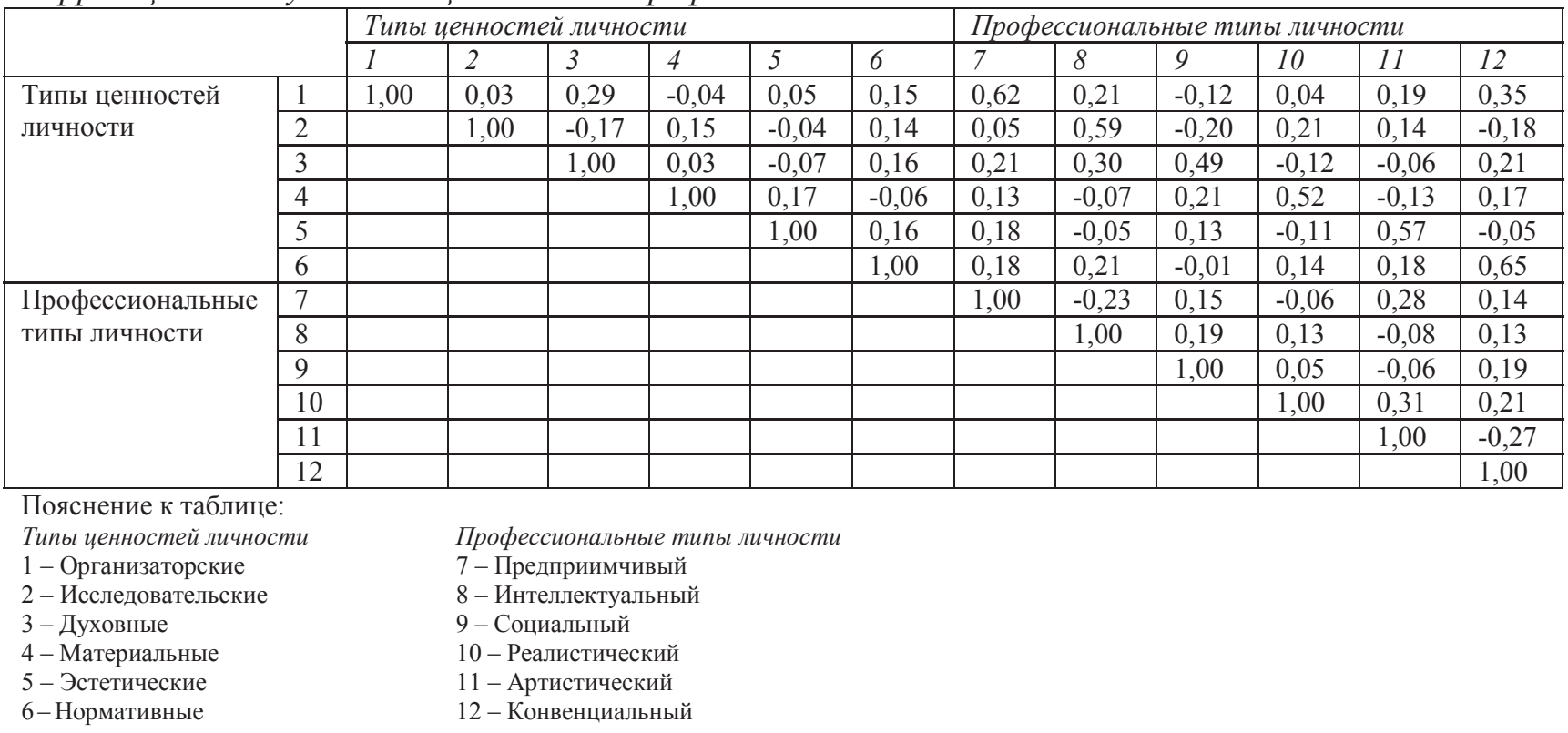

Эталонный валидный тест является независимым критерием и в данном случае позволяет проверить критериальную валидность вновь созданного теста [Кулагин, 1984]. Использование принципа семантической близости позволяет установить взаимно-однозначное соответствие психологических характеристик типов ценностей личности и типов профессиональной направленности личности («типологический изоморфизм») [Малышев, 2019].

Можно построить изоморфизм трехмерной прямоугольной системы координат XYZ, имеющей шесть направлений на осях, и «типологической снежсинки» с тремя «разветвлениямитипами» на каждой оси. Всего будет $18(3 \times 6)$ типов, которые соответствуют 18 диагностическим суждениям теста (см. Рис. 2).

В центре этой структуры будет начало трехмерной системы координат и центр («середина») «измерительной типологической снежинки» [Mалышев, 2019]. Помещаем начало координат этой системы в середину этой снежинки, а оси-векторы будут направлены к основаниям веток, состоящих из $15(5 \times 3)$ «маленьких ответвлений-оценочных измерителей» (см. Рис. 3).
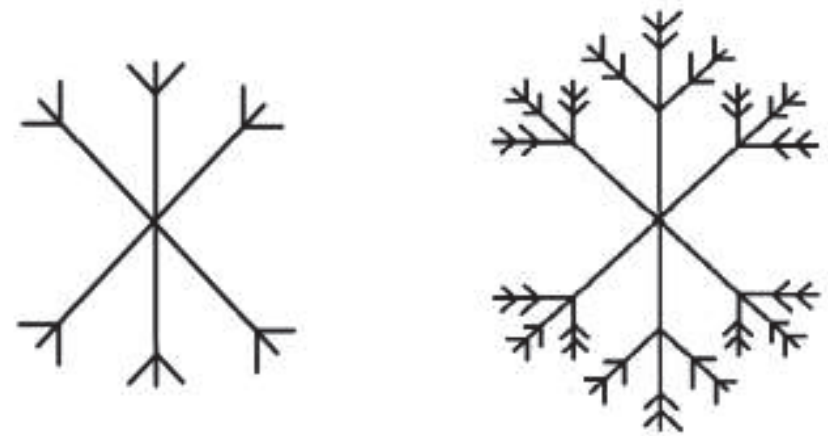

Рис. 2. Плоскостное представление трехмерного базиса в виде «типологической снежинки»
Рис. 3. Плоскостное представление трехмерного базиса в виде

«измерительной типологической снежинки» 
На Рисунке 2 шесть линий-векторов определяют 6 типов, каждый из которых содержит еще три подтипа. В итоге получается 18 (3×6) подтипов. На рисунке 3 на каждом из 18 подтипов находится 5 «оценочных измерителей», которые связаны с симметрической пятибалльной шкалой оценки от -2 до +2: полностью не согласен (-2), скорее не согласен, чем согласен (-1), неопределенный случай (0), скорее согласен, чем не согласен $(+1)$, полностью согласен $(+2)$.

Эта симметрическая шкала оценки отображается на шкалу: 1, 2, 3, 4, 5 .

В природе известны шестиэлементные структурные образования, которые при восприятии являются «устойчивыми» «системно-базисными трехмерными» структурами: ячейки пчелиных сот или снежинки. Это пример подтверждает принцип «природосообразности», то есть природа «подсказывает» и «намекает» на существование таких «устойчивых» базисных структур в мире [Малышев, 2019].

Bblводыl. Результаты исследования позволяют усовершенствовать измерение ценностей личности на основе применения многомерного базисного типологического подхода, что, в свою очередь, даст возможность улучшить практическое диагностическое обеспечение психолога. Информация, полученная в результате исследования, может быть использована для творческого развития как теоретического, так и практического психолога при проведении им психодиагностики, тренингов, деловых игр, психологического консультирования. Результаты исследования можно использовать при разработке новой системно-базисной многомерной педагогической технологии для улучшения качества преподавания психологических дисциплин в учебных заведениях. Основные положения данного подхода можно, в частности, использовать для расширения содержания учебного курса «Психодиагностика». Цель исследования была достигнута, задачи решены и гипотеза в итоге была подтверждена.

\section{Библиографический список}

1. Вейль Г. Симметрия. Москва : Наука, 1968. $132 \mathrm{c}$.

2. Ганзен В. А. Системные описания в психологии. Ленинград : ЛГУ, 1984. $176 \mathrm{c}$.

3. Кеплер И. О шестиугольных снежинках. Москва : Наука, 1983. 123 с.

4. Кузьмин В. П. Исторические предпосылки и гносеологические основания системного подхода // Психологический журнал. 1982. Т. 3. № 3. С. 3-14; T. 3. № 4. C. 3-13.
5. Кулагин Б. В. Основы профессиональной психодиагностики. Ленинград : Медицина, 1984. 149 с.

6. Ломов Б. Ф. О системном подходе в психологии // Вопросы психологии. 1975. № 2. С. 31-45.

7. Мазилов В. А. Методология психологической науки: история и современность. Ярославль : РИО ЯГПУ, 2017. $419 \mathrm{c}$.

8. Малышев К. Б. Системные описания типологий / К. Б. Малышев, О.А.Малышева. Вологда ; Курск, 2019. 226 с.

9. Малышев, К. Б. Системно-факторный анализ в психологии / К. Б. Малышев, О. А. Малышева. Вологда ; Курск, 2019. 180 с.

10. Принцип системности в психологических исследованиях / под ред. Д. Н. Завалишиной, В. А. Барабанщикова. Москва : Наука, 1990. 178 с.

11. Солонкина О.В. Психодиагностика в социально-культурном сервисе и туризме / О. В. Солонкина, Д. М. Рамендик. Москва : ACADEMA, 2004. 224 c.

12. Шафрановский И. И. Симметрия в природе. Ленинград : Недра, 1968. 154 с.

13. «European Portfolio for Student Teachers of Languages»/ David Newby, Rebecca Alan, Anne-Brit Fenner, and others. Graz: European Centre for Modern Languages, 2007. 89 p.

14. Carroll B J. Testing Communicative performance. An Interim study. Oxford: Oxford University Press, 1980. $149 \mathrm{p}$.

15. Common European Framework for Reference: Learning, Teaching, Assessment. Cambridge : Cambridge University Press, 2001. 260 p.

16. Maley A. (series editor). Resource Books for Teachers. London: Oxford University Press, 1997.

17. Miller G. A., McNeillD. Psycholinguistics // The Handbook of SociPsychology, vol. 3. N. Y., 1969.

18. Nuttel C. Teaching Reading Skills in a Foreign Language. Oxford: Macmillan Books for Teachers, 2005. $282 \mathrm{p}$.

19. Wallace M. J. Training Foreign Language Teachers: A Reflective Approach. Cambridge: Cambridge University Press, 1991. $180 \mathrm{p}$.

20. Allport, G. W. Trait-Names: a psyho-lexsikal study G. W. Allport, H. S. Odbert // Psychological Monographs. 1936. V. 47. P. 1-171, 211.

\section{Reference list}

1. Vejl' G. Simmetrija = Symmetry. Moskva : Nauka, 1968. $132 \mathrm{~s}$.

2. Ganzen V. A. Sistemnye opisanija v psihologii $=$ System descriptions in psychology. Leningrad: LGU, 1984. $176 \mathrm{~s}$.

3. Kepler I. O shestiugol'nyh snezhinkah $=$ About hexagonal snowflakes. Moskva : Nauka, 1983. 123 s.

4. Kuz'min V. P. Istoricheskie predposylki i gnoseologicheskie osnovanija sistemnogo podhoda $=$ Historical background and epistemological basis of the systemic approach // Psihologicheskij zhurnal. 1982. T. 3. № 3. S. 3-14; T. 3, № 4. S. 3-13. 
5. Kulagin B. V. Osnovy professional'noj psihodiagnostiki $=$ Fundamentals of professional psychodiagnostics Leningrad : Medicina, 1984. $149 \mathrm{~s}$.

6. Lomov B. F. O sistemnom podhode $\mathrm{v}$ psihologii $=$ On the systemic approach in psychology // Voprosy psihologii. 1975. № 2. S. 31-45.

7. Mazilov V.A. Metodologija psihologicheskoj nauki $=$ Methodology of psychological science: istorija $\mathrm{i}$ sovremennost'. Jaroslavl' : RIO JaGPU, 2017. 419 s.

8. Malyshev K. B. Sistemnye opisanija tipologij= System descriptions of typologies / K. B. Malyshev, O. A. Malysheva. Vologda ; Kursk, 2019. 226 s.

9. Malyshev, K. B. Sistemno-faktornyj analiz v psihologii $=$ System-factor analysis in psychology $/$ K. B. Malyshev, O. A. Malysheva. Vologda ; Kursk, 2019. $180 \mathrm{~s}$.

10. Princip sistemnosti v psihologicheskih issledovanijah $=$ The principle of systemic in psychological re-

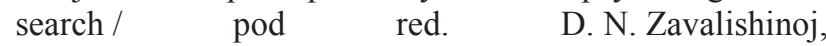
V. A. Barabanshhikova. Moskva : Nauka, 1990. 178 s.

11. Solonkina O. V. Psihodiagnostika v social'nokul'turnom servise i turizme $=$ Psychodiagnostics in social and cultural services and tourism/ O. V. Solonkina, D. M. Ramendik. Moskva : ACADEMA, 2004. 224 c.
12. Shafranovskij I. I. Simmetrija v prirode = Symmetry in nature. Leningrad : Nedra, 1968. $154 \mathrm{~s}$.

13. «European Portfolio for Student Teachers of Languages»/ David Newby, Rebecca Alan, Anne-Brit Fenner, and others. Graz : European Centre for Modern Languages, 2007. 89 p.

14. Carroll V J. Testing Communicative performance. An Interim study. Oxford: Oxford University Press, 1980. 149 p.

15. Common European Framework for Reference: Learning, Teaching, Assessment. Cambridge : Cambridge University Press, 2001. 260 p.

16. Maley A. (series editor). Resource Books for Teachers. London: Oxford University Press, 1997.

17. Miller G. A., McNeillD. Psycholinguistics // The Handbook of SociPsychology, vol. 3. N. Y., 1969.

18. Nuttel C. Teaching Reading Skills in a Foreign Language. Oxford: Macmillan Books for Teachers, 2005. $282 \mathrm{p}$.

19. Wallace M. J. Training Foreign Language Teachers: A Reflective Approach. Cambridge: Cambridge University Press, 1991. 180 p.

20. Allport, G. W. Trait-Names: a psyho-lexsikal study G. W. Allport, H. S. Odbert // Psychological Monographs. 1936. V. 47. P. 1-171, 211. 